INTERNATIONAL JOURNAL OF MULTIDisciplinARY RESEARCH AND ANALYSis

ISSN(print): 2643-9840, ISSN(online): 2643-9875

Volume 04 Issue 05 May 2021

DOI: 10.47191/ijmra/v4-i5-24, Impact Factor: 6.072

Page No. - 651-662

\title{
Fiscal Decentralization and Macroeconomic Outcomes in Nigeria
}

\author{
QUESTION, Emomotimi McDonald ${ }^{1}$, ENIEKEZIMENE, Ariayefa Francis ${ }^{2}$ Ph. D \\ 1,2Department of Economics, Niger Delta University, Wilberforce Island Bayelsa State, Nigeria.
}

ABSTRACT: This study examined the fiscal decentralization-economic growth nexus in Nigeria, with the objective of establishing the causal relationship between measures of fiscal decentralization and economic growth covering the period 1981-2019. Employing the autoregressive distributed lag (ARDL) technique of econometrics, the analyses revealed that fiscal decentralization variables employed in the study vis-a-vis federal government, state government and local government expenditures have a positive and significant impact on economic growth in Nigeria except for local government expenditure which was not significant at any level. This behaviour is adduced to be a function of poor governance, corruption and other underlying structural challenges at that level. Also, it was observed that while real GDP has a positive and significant impact on private consumption expenditure, its impact on unemployment was not significant at any level. The study therefore concludes that the nature and pattern of growth in Nigeria has not been inclusive. Consequently, it is recommended that fiscal relations governing the different tiers of government be reviewed to meet existing realities while coordinated fiscal policy measures and improved governance will enhance growth and the fiscal space in the country.

\section{INTRODUCTION}

Fiscal decentralization involves the devolution of powers from the central government to subnational governments. It is no more than increase in taxing and or spending responsibilities given to subnational jurisdiction (Tanzi 2001). There are many reasons why countries tend to gravitate towards fiscal decentralization. The most prominent argument has been the efficiency criteria. This is the view that fiscal decentralization gives access to symmetric information which allows matching of public expenditure to local preferences thereby enhancing allocative efficiency and by extension economic growth. According to Martinez-Vasquez and McNab (2001), fiscal decentralization has become endearing mainly due to the consideration that it will boost the efficiency of public expenditures, and the fact that it is seen as a means of breaking the central government's grip on the economy by shifting fiscal authority to subnational governments. Tanzi (2001), asserts that the convergence among nations towards fiscal decentralization is borne out of the following: the deepening democratization which has given rise to more voice and weight to the preferences of specific groups and regions; the rise of globalization leading to market areas that are no longer identical national territories; decentralization taking the form of a superior good which has become more desirable following rising income; and finally, the desire of richer regions through awareness to crave for more independence.

Despite these attractions above, researchers have cautioned that decentralization carries certain drawbacks that could derail the possible gains highlighted. These include the belief that decentralization may impose constraints to the implementation of coordination channels across regions (Guldner 1995). This could inhibit growth where central government policies are at variance with those of subnational governments thereby causing policies to be counterproductive. Horizontal fiscal imbalances across lower tiers of government and challenges to macroeconomic stability are possible drawbacks to fiscal decentralization (MartinezVasquez and McNab 2001). Notwithstanding the identified possible drawbacks, fiscal decentralization continues to be desirable given the efficiency criteria and other arguments cited above.

Nigeria practices fiscal decentralization and over the years, the federating units and tiers of government have shared huge amounts of resources for the purposes of meeting expenditure responsibilities. However, it is hard to see a correlation between the amount of money spent and the prevailing macroeconomic conditions in the country. The country is fraught with rising levels of poverty and unemployment, decay in public infrastructure and high levels of inflation.

This tends to negate the argument for fiscal decentralization that it engenders economic growth through allocative efficiency. The motivation for the study therefore is to determine if there is a causal relationship between fiscal decentralization and macroeconomic aggregates given the prevailing macroeconomic conditions in the country. This work is different from recent 


\section{Fiscal Decentralization and Macroeconomic Outcomes in Nigeria}

literature which mostly examined the fiscal decentralization-growth nexus without necessarily investigating the dynamic macroeconomic interactions that affect the growth process. Hence, the study will determine the impact of fiscal decentralization on, unemployment, private consumption expenditure and the unemployment rate. These still corresponds to goals of fiscal decentralization, in line with Musgrave's framework of three core government functions of: stabilization, distribution and allocation (Musgrave, 1959; Musgrave and Musgrave, 1984). Investigating the interactions between fiscal decentralization and the above macro aggregates will tell how fiscal decentralization affects welfare of the average citizen which is invaluable for policy. The remainder of the study is organized in the following order. Section 2 reviews the existing literature on the link between fiscal decentralization and macroeconomic outcomes. Section 3 deals with the methodology and data used for the empirical analysis. Section 4 reports the estimation results while section 5 provides some concluding remarks.

\section{LITERATURE REVIEW}

The literature has advanced some very cogent reasons for the case for fiscal decentralization. These transcend both socioeconomic and political criteria why decentralization tends to draw support. From an economic perspective, Oates (1972) in the theorem of decentralization asserts that a Pareto efficient level of output for a public good can better be provided at a local government level than a central government to provide at uniform solutions across all jurisdictions. This is necessary where such a public good does not carry externalities that transcend the jurisdiction of the local government. In public policy theory, government activity is divided into allocation, distribution and stabilization functions (Musgrave 1959). This classification puts stabilization and distribution functions under the sphere of the central government while the allocation function is shared between the central and subnational governments. In the literature, the argument is that the central government is better placed to perform the distribution and stabilization functions as well as provide national public goods (Oates, 1972; Musgrave and Musgrave, 1984; Taiwo, 1999).

These functions will be inefficiently performed at the subnational government level for two interrelated reasons; difficulty in appropriating the full social benefits of the programme undertaken at that level, and the principle of non-exclusion which generates the problem of the free rider. About the former, the local government tends to take into consideration only its own marginal costs and benefits when deciding on its level of provision, and ignores the benefits conferred on other local governments. A public good that cannot exclude free riders from benefitting can only be efficiently provided by the central government in a federal system being the government of all citizens, hence stabilization and distributive functions follows this reasoning. This is because for a subnational government to produce a good that it cannot exclude non-residents from benefitting, it has already created a negative externality borne by its constituents which if produced by the central government; such costs will be internalized (Layard and Walters, 1978).

When it comes to the provision of public goods at the local level, the decentralization theorem is explicit on the economic efficiency criteria that in producing public goods a region or local government authority will adapt output of public services to the preferences and peculiar conditions of the constituents than a central government which is far off and may not actually understand the local preferences. Here allocative efficiency can be achieved in the production of a local public good by the local authority which better appreciates and match local preferences to public outputs.

The Tiebout (1956) hypothesis wherein Decentralization breeds competition among local jurisdiction which leads to efficiency as budgetary constraints potentially causes local jurisdictions to source for economically efficient methods in the provision of public services results in general improvement and welfare. It thus follows that mobile households can seek out jurisdictions that provide public goods that suite their tastes thereby harnessing the surplus value that comes from the decentralized provision of public services. Fiscal decentralization also promotes experimentation which breeds innovation as individual jurisdictions have the freedom to try and adopt new approaches to public policy that promotes efficiency.

The above are economic reasons why fiscal decentralization seem endearing to many countries. From a political perspective, federalism could occur following the match to maturity of the political process through conscious application of the constitution in nation building, as communities or groups deliberately embrace functional arrangement that promote unity in diversity to the benefit of all (Ramphal, 1979).

\subsection{Theoretical framework}

\subsubsection{Decentralization Theorem}

The Decentralization Theorem developed first by Oates (1972: 35) states:

"For a public good, the consumption of which is defined over geographical subsets of the total population, and for which the costs of providing each level of output of the good in each jurisdiction are the same for the central or for the respective local government, it will always be more efficient (or at least as efficient) for local governments to provide the Pareto-efficient levels of output for 


\section{Fiscal Decentralization and Macroeconomic Outcomes in Nigeria}

their respective jurisdictions than for the central government to provide any specified and uniform level of output across all jurisdictions".

Decentralization theorem from Oates' perspective views government as a benevolent agent which in the presence of diverse preferences and needs provides services from a decentralized arrangement that leads to increased citizens' welfare. This is possible because decentralized government leads to symmetric information advantages and more flexibility in adapting to citizens' needs and preferences, Hayek (1945). The theory is in tandem with Musgrave (1959) which divides government economic responsibilities to allocation, distribution and stabilization functions.

From the foregoing, role assignment on the basis of functions of government requires that the central government is better equipped to ensure equitable distribution of income, maintain macroeconomic stability and provide public goods that are national in character. Decentralized levels of government on the other hand are better placed to provide local public good with the central government providing targeted grants in cases where there are jurisdictional spill-overs associated with local public goods. This arrangement is expected to engender efficiency in resource allocation and lead to welfare optimization. This is the core of the theory of decentralization.

\subsubsection{Keynesian Aggregate Expenditure Model}

In the simple Keynesian model where total output is a function of aggregate expenditure explains the role of government in the determination of real output as well as generation of employment. Also, the stabilization function mentioned in Musgrave is adequately captured in the Keynesian model.

To start with, the Keynesian model is given as:

$$
Y=C+I+G+(X-M)
$$

Where:

$\mathrm{Y}$ is total output, $\mathrm{C}$ is consumption expenditure, I is investment expenditure, $\mathrm{G}$ is government expenditure and $\mathrm{X}-\mathrm{M}$ stands for net exports.

$\mathrm{Y}$ which is GDP is determined at equilibrium by the interaction of the aggregate expenditure consisting of the four components above. Two key assumptions of the model are: (1) there is a specific rate of output associated with full employment. (2) Prices and wages are flexible below full employment output.

The largest component of aggregate expenditure is consumption which spurs other components of the model towards full employment output. When income increase and households spend more on consumption expenditure, business firms respond to rising demand by investing more after drawing down of their inventory. More investment requires more labour which leads to higher employment. On the part of government, increased investment and consumption generates more income which government can tax from both the businesses and households. In turn, the revenue realized is used to fund government expenditure which is the provision of public goods and services. The final component of the model is exports and imports. Exports are independent of the level of income as it is foreign demand while imports are dependent on the level of income. Households, firms and government will tend to demand more of foreign goods as the level of income increases.

Our concern though for this study is the government and consumption expenditure components of the model. In this model government expenditure is a function of the political process and not consumers income or spending. Government spends to correct market failure; as such government spends more than it receives in taxes in some cases to correct such market failures. In the end, it boils than to the fact that, government expenditure in the provision of public goods leads to creation of employment, increased output as well as stabilize the economy through taxation or spending which are the core activities highlighted by Musgrave as government's functions.

On consumption expenditure, it is the largest component of the model and it drives growth. Household consumption expenditure must be thriving to spur the other economic agents such as businesses, government and foreign demand. The dynamic interactions between these variables drive growth and causes macroeconomic outcomes. The Keynesian model explains how prices can rise rapidly in the short-run when consumption outweighs the level of output especially when the economy is operating below the full employment level. Such imbalances according to Keynes can be corrected through active government intervention. Based on the above, this study in conjunction with the decentralization theorem adopts the Keynesian aggregate expenditure model in analysing the dynamic interactions of the variables in the study.

\subsection{Empirical literature}

The efficiency criteria posit that fiscal decentralization enhances economic efficiency by matching local preferences to public expenditure targets thereby causing allocative efficiency with a corresponding effect on the dynamic setting of economic growth (Oates 1993). Decentralization could influence growth indirectly with its impact on other economic variables (Martínez-Vázquez \& McNab, 2001). Empirical evidence on this is mixed, with Jin and Rider (2020) among others finding negative impacts. Martínez- 


\section{Fiscal Decentralization and Macroeconomic Outcomes in Nigeria}

Vázquez \& McNab (2003) cited no direct effect on economic growth but an indirect effect through macro stability. Feld et al. (2004) discovered in Switzerland that, significant subnational fiscal autonomy has contributed to faster economic growth; as such matching grants from the center engender economic growth. Hanif et al (2020) examined the impact of fiscal decentralization on fifteen federally developing countries using panel data and the application of a two-step system Generalized Method of Moments (GMM) estimation method, the study revealed that tax revenue and expenditure decentralization has a significant and positive impact on economic growth. Canavire-Bacarreza et al (2019), examined the impact of fiscal decentralization on economic growth by using Geographic Fragmentation Index and Country Size as instrumental Variables alongside the conventional measures of decentralization, employing OLS as method of study. The findings show a positive and significant impact of fiscal decentralization on economic growth. Ewetan, et al (2020) examined the fiscal federalism-economic development nexus in Nigeria from 19812017 using ARDL method. The study revealed that revenue decentralization has a negative and significant impact on economic development while expenditure decentralization was positive and significantly related to economic development. Amire, and Okufuwa, (2020) examined the impact of fiscal federalism on Economic Development in Nigeria using multiple regression analysis. The study revealed that the measures of fiscal decentralization; states internally generated revenue, allocations from the federation account to federal, states and local governments has a long run relationship with measures of development viz: per capita income; literacy and infant mortality except for revenue to local government areas. Udoh, et al (2015) used ARDL/Bounds Testing approach in their study and revealed that expenditure decentralization exerted negative effect on human resource development in Nigeria. The study showed that the nature of expenditure decentralization in Nigeria, in the long-run, tend to induce inefficient application of resources with implications on the cost of governance rather than cost minimization in public expenditure.

Generally, empirical evidence has shown no consensus on the impact of fiscal decentralization on macroeconomic outcomes as revealed by the review. Studies have shown both positive and negative impact of fiscal decentralization on macroeconomic outcomes. These results motivate the need for further studies on fiscal decentralization- macroeconomic outcomes nexus.

\section{METHODOLOGY}

The basic analytical idea of this work is built on the fiscal decentralization theorem as mentioned in our theoretical framework. It is adopted in line with the Keynesian theory of income determination which succinctly calls for an active government interventionist approach in correcting problems of market failure in the economy. This provides the study the necessary framework to build a model that can explain the relationships inherent in the work. Thus, the focus is to adopt an econometric model which will facilitate parameter estimation, model specification and the conduct of appropriate statistical and econometrics tests that will enhance policy formulation. Consequently, the study used an Autoregressive Distributed Lag (ARDL) Bound Test model given its ability to circumvent the problem of the order of integration associated with the Johansen likelihood approach (Johansen and Juselius, 1990). Secondly, unlike most of the conventional multivariate cointegration procedures, which are valid for large sample size, the bounds approach is suitable for small sample size studies, (Pesaran et al, 2001); and it provides unbiased estimates of the long-run model and valid t-statistics even when some of the regressors are endogenous (Harris and Sollis, 2003).

This study follows Davoodi and Zou (1998) by assuming that public spending is carried out by three levels of government namely: federal, state and local as adopted by Adefeso (2014). Assume that $\mathrm{G}$ is the total public spending on the provision of public services and it is the composition of F, Federal Government spending, S, State Government spending and L, Local Government spending. i.e:

$$
\mathrm{G}=\mathrm{F}+\mathrm{S}+\mathrm{L}
$$

Functionally put:

$$
Y=f(\text { FGEX, SGEX, and LGEX). }
$$

Where: $Y=$ Economic performance, proxied by Economic Growth (RGDP); Unemployment rate (UMPR) and Private Consumption Expenditure (PCEX) while FGEX, SGEX and LGX are the expenditures of the federal, states and local governments respectively. Econometrically:

Where:

$$
Y_{t}=a_{0}+a_{1} F G E X_{t}+a_{2} S G E X_{t}+a_{3} L G E X_{t}+U_{t} .
$$

$Y_{t}$ is Economic performance at time $t$, where $t$ is the number of time periods i.e. $(t=1,2 \ldots . N)$ a0 is the intercept of the slope while $\alpha 1-\alpha_{3}$ are parameter estimates. FGEX, SGEX, and LGX are the measures of fiscal decentralization in expenditure variables respectively and $\mu_{t}$ is the disturbance term which is assumed to be serially uncorrelated and white noise to the explanatory variables. The focus of this research is the coefficients of the fiscal decentralization variables, which may be positive or negative and statistically significant given the conventional arguments in favour or against fiscal decentralization policy. 


\section{Fiscal Decentralization and Macroeconomic Outcomes in Nigeria}

Based on equation (3.3) we apply the Autoregressive Distributed Lag (ARDL)/bounds testing cointegration method to estimate the long run and short run relationships and dynamic interaction among the variables in the model. Pesaran et al (2001) proposed an ARDL/Bounds Testing approach to investigate the existence of cointegration relationship among variables when testing for short and long run impact. Consequently, the basic ARDL model of the study is specified as follows:

$\Delta \operatorname{lnRGDP} t=C_{0}+\alpha_{1} \operatorname{lnRGDP} P_{\mathrm{t}-1}+\alpha_{2} \ln U M P R+\alpha_{3} \ln P C E X+\alpha_{4} \operatorname{lnFD} \mathrm{t}-\mathrm{i}+\sum \delta \alpha_{1} \Delta \ln R G D P_{\mathrm{t}-1}+\sum \forall \alpha_{2} \Delta \ln U M P R+\sum \delta \alpha_{3} \Delta \ln P C E X+\sum \mathrm{p} \alpha_{4} \Delta \ln F D+$

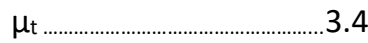

$\ln U M P R_{\mathrm{t}-1}=\mathrm{C}_{0}+\Delta \ln U M P R+\alpha_{2} \operatorname{lnRGDP} \mathrm{t}_{\mathrm{t}-1}+\alpha_{4} \operatorname{lnFD_{\mathrm {t}-1}}+\sum \mathrm{t} \alpha_{2} \Delta \ln U M P R+\sum \delta \alpha_{1} \Delta \operatorname{lnRGDP} \mathrm{t-1}+\sum \mathrm{p}_{4} \Delta \operatorname{lnFD}_{\mathrm{t}-\mathrm{I}}+\mu_{\mathrm{t}}$

$\ln P C E X_{t}=C_{0}+\alpha_{1} \operatorname{lnPCEX}_{\mathrm{t}-1}+\alpha_{2} \operatorname{lnRGDP}_{\mathrm{t}-1}+\alpha_{3} \operatorname{lnFD}_{\mathrm{t}-1}+\sum \mathrm{\psi} \alpha_{1} \Delta \ln \operatorname{lnCEX}_{\mathrm{t}-1}+$

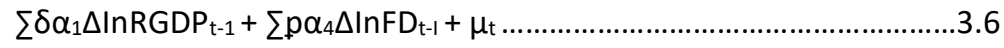

Where: $\alpha_{\mathrm{i}}$ are the long run multipliers, $\mathrm{c}_{0}$ is the intercept, FD is the various measures of fiscal decentralized expenditure and $\mu_{\mathrm{t}}$ is a white noise error term.

Equations 3.4-3.6 represent the models for our three (3) objectives which are to determine the interactions between fiscal decentralization and macroeconomic outcomes in terms of economic growth; unemployment rate and private consumption expenditure in Nigeria. Equation (3.4) represents the dynamic interaction between economic growth, represented by RGDP and fiscal decentralization represented by the fiscal expenditure of the three tiers of government in Nigeria.

Unemployment and private consumption expenditure serve as dependent variables in equations (3.5) and (3.6) respectively and regressed on growth and fiscal decentralization. ARDL bounds testing approach is estimated by subjecting equation (1-3) to Ordinary Least Squares (OLS) test to determine the existence of a long-run relationship among the variables in the model. The Ftest is then used to confirm the overall significance of the coefficients of the lagged levels of the variables. The F-statistics is compared with the lower and upper bounds of two asymptotic critical values to test for cointegration when the independent variables are $\mathrm{I}(\mathrm{d})$ [where $0 \leq d \leq 1$ ]: a lower value assuming the regressors are $\mathrm{I}(0)$ and an upper value assuming purely $\mathrm{I}(1)$ regressors. If the F-statistic is above the upper critical value, the null hypothesis of no long run relationship can be rejected irrespective of the orders of integration and the alternate accepted that there is long run equilibrium.

\section{PRESENTATION AND DISCUSSION OF RESULTS.}

\subsection{Unit Root Test.}

The study used the Augumented Dickey Fuller test to determine the presence of unit root in the series using intercept without trend and intercept with trend models. As shown in Table 4.1 all the variables are found stationary after converting them to first difference. Nevertheless, the test rejects the null hypothesis of unit root at most in first difference.

Table 4.1: Augmented Dickey Fuller Unit Root Test

\begin{tabular}{|c|c|c|c|c|}
\hline \multirow{2}{*}{ Series } & \multicolumn{2}{|c|}{ Intercept without trend } & \multicolumn{2}{|c|}{ Intercept with trend } \\
\hline & Level & $1^{\text {st }}$ Difference & Level & $1^{\text {st }}$ Difference \\
\hline $\operatorname{Lrgdp}$ & -0.097 & $-3.433^{* *}$ & -1.486 & $-3.35^{*}$ \\
\hline Lpcex & -1.486 & $-8.977 * * *$ & $3.685^{* *}$ & $-9.295 * * *$ \\
\hline Lfgex & -1.421 & -1.994 & -0.423 & $-7.708 * * *$ \\
\hline Lsgex & -0.768 & -0.421 & $-3.618^{* *}$ & $-3.640 * *$ \\
\hline Llgex & 0.039 & -4.838 & $-3.497 *$ & $4.779 * * *$ \\
\hline Lumpr & $-3.663 * * *$ & $-5.605 * * *$ & $-3.842 * *$ & $5.531 * * *$ \\
\hline Infr & $-3.763 * * *$ & $-5.375 * * *$ & $-4.842 * *$ & $4.531 * * *$ \\
\hline
\end{tabular}

The acronyms, RGDP, PCEX, FGEX, SGEX, LGEX, UMPR and INFR represent real GDP, private consumption expenditure, federal government expenditure, state government expenditure, local government expenditure, unemployment rate and inflation rate, respectively. The asterisks, ***,** and * indicate rejection of null hypothesis of no correlation among the variables at $1 \%, 5 \%$ and $10 \%$ respectively.

Source: Authors' Computation

\subsection{ARDL Cointegration Test}

The bound test for cointegration is estimated to determine whether there is cointegration among the variables captured in the ARDL model. This has been achieved using the bound testing approach and the results are presented in Table 4.2. 
Fiscal Decentralization and Macroeconomic Outcomes in Nigeria

Table 4.2.: ARDL Bound Cointegration Test

\begin{tabular}{|c|c|c|c|c|}
\hline \multirow{2}{*}{ Model } & \multirow{2}{*}{ F-Stat. } & \multirow{2}{*}{ Sig. Level. } & \multicolumn{2}{|c|}{ Critical Value } \\
\hline & & & $\mathrm{I}(0)$ & $\mathrm{I}(1)$ \\
\hline LRGDP $=F(L P C E X, L F G E X, L S G E X, L L G E X, L U M P R, L I N F R)$ & $4.457 * *$ & $10 \%$ & 2.26 & 3.35 \\
\hline LPCEX $=F(L R G D P, L F G E X, L S G E X, L L G E X, L U M P R, L I N F R)$ & $5.104^{* * *}$ & $5 \%$ & 2.62 & 3.79 \\
\hline LFGEX $=F(L R G D P, L P C E X, L S G E X, L L G E X, L U M P R$ LINFR) & 1.239 & $1 \%$ & 3.41 & 4.68 \\
\hline LSGEX $=F(L R G D P, L P C E X, L F G E X, L L G E X, L U M P R$ LINFR) & $5.799 * * *$ & & & \\
\hline LLGEX $=F(L R G D P, L P C E X, L F G E X, L S G E X, L U M P R, L I N F R)$ & $3.835^{* *}$ & & & \\
\hline LUMPR $=F(L R G D P, L P C E X, L F G E X, L S G E X, L L G E X$ LINFR) & $3.323^{*}$ & & & \\
\hline INFR $=F(L R G D P, L P C E X, L F G E X, L S G E X, L L G E X$ LUMPR) & $2.212^{*}$ & & & \\
\hline
\end{tabular}

Note: $* * *, * *$ and $*$ represent significance level at $1 \%, 5 \%$ and $10 \%$ respectively. The critical values are based on Narayan (2005), case III for $\mathrm{T}=35$ due to small sample size of the study.

Source: Researcher's Computation

The cointegration tests have shown four vectors of long run relationship. However, for the purpose of this study, it can be determined from Table 4.2 that when LRGDP and LPCEX are the dependent variables, the F-statistics of 4.457 and 5.104 are higher than the 3.79 and 3.35 asymptotic critical values at $5 \%$ and $10 \%$ respectively. Hence the null hypothesis of no long run equilibrium is rejected in place of the alternate hypothesis that a long run relationship exists. In the case of the unemployment UMPR, the Fstatistics of 3.323 is lower than the critical lower and upper bounds of 3.41 and 4.68 ; hence the null hypothesis is accepted that no long run equilibrium exists. The cointegration results give us the room to determine the existing relationships in the model.

\subsection{Relationship between Fiscal Decentralization and RGDP}

Table 4.3. RGDP Model

Long Run Coefficients

\begin{tabular}{cc}
\hline Variables & $0.224^{*}$ \\
\hline Lpcex & $(1.409)$ \\
Lfgex & $0.164^{* *}$ \\
& $(2.248)$ \\
Lsgex & $0.183^{* *}$ \\
& $(2.207)$ \\
Llgex & 0.379 \\
& $(7.992)$ \\
Lumpr & $-0.007^{* *}$ \\
& $(-0.237)$ \\
Infr & $-0.002^{* *}$ \\
Constant & $(-1.567)$ \\
& $11.275^{* * *}$ \\
\hline
\end{tabular}

Note: $* * *(* *) *$ denote statistical significance at the $1 \%, 5 \%$, and $10 \%$ levels, respectively. The figures in parentheses are the T-statistics.

Source: Researcher's Computation

We start by determining the long run relationship. Table 4.3 indicates that the FD variables LFGEX (0.164) and LSGEX (0.184) coefficients are positive and significant effects on RGDP. However, LLGEX (0.379) though, has no significant effect on RGDP in the long run. The results are consistent with a priori expectation despite LGEX not been significant. For the control variables; PCEX, UMPR and INFR they exhibited the expected behaviour and are properly signed. 


\section{Fiscal Decentralization and Macroeconomic Outcomes in Nigeria}

Table 4.4

Short Run Coefficients

\begin{tabular}{|c|c|}
\hline Variables & \\
\hline \multirow[t]{2}{*}{$\mathrm{D}($ /pcex $)$} & $0.135^{* * *}$ \\
\hline & (3.125) \\
\hline \multirow[t]{2}{*}{$\mathrm{D}($ lfgex $)$} & $0.042 * * *$ \\
\hline & (1.683) \\
\hline \multirow[t]{2}{*}{$\mathrm{D}($ /sgex $)$} & $0.007 * *$ \\
\hline & $(0.221)$ \\
\hline \multirow[t]{2}{*}{$\mathrm{D}($ /lgex $)$} & 0.022 \\
\hline & (2.320) \\
\hline \multirow[t]{2}{*}{$\mathrm{D}($ lumpr $)$} & $-0.003 * *$ \\
\hline & $(-0.519)$ \\
\hline \multirow[t]{2}{*}{$\mathrm{D}($ infr $)$} & $-0.220 * *$ \\
\hline & $(-0.612)$ \\
\hline \multirow[t]{2}{*}{ CointEq(-1) } & $-0.293 * * *$ \\
\hline & $(-4.862)$ \\
\hline
\end{tabular}

Note: $* * *(* *) *$ denote statistical significance at the $1 \%, 5 \%$, and $10 \%$ levels, respectively. The figures in parentheses are the T-statistics.

Source: Researcher's Computation

The short run analysis in table 4.4 shows that the results followed the long run dynamics. Both LFGEX and LSGEX are positive and significant at $10 \%$ and $5 \%$ respectively while LLGEX though positive is not significant at any conventional level of significance. The control variables exhibited the long run dynamics and are significant at conventional levels. The error correction mechanism of 0.293 is indicates that short run distortions of the model will be corrected up to $29 \%$ in the subsequent year.

The interesting thing about the results is the performance of Local Government expenditure which is not significant at any conventional level both in the short and long runs. Now this outcome is not surprising in that governance at that level of government in the country is almost non-existent and fraught with corruption and local capture. Consequently, the insignificant outcome of the result only shows the underlying challenges at that level of government. Also, it indicates that with concerted and deliberate efforts towards service delivery, the contribution of that tier of government will become significant.

\subsubsection{Relationship between Fiscal Decentralization and Private Consumption Expenditure}

The study also investigates the relationship between fiscal decentralization and private consumption expenditure in Nigeria. The cointegration, which is long-run equilibrium of private consumption and fiscal decentralization, is established in Table 4.2. The results showing the causal relationship between the variables are presented in Tables 4.5 and 4.6 for the long run and short run coefficients respectively.

Table 4.5 ARDL results of PCEX model.

Long Run Coefficients

\begin{tabular}{ll}
\hline Variables & \\
\hline LFGEX & $0.479^{* *}$ \\
& $(2.174)$ \\
LSGEX & $0.586^{* *}$ \\
& $(2.446)$ \\
LLGEX & $0.418^{*}$ \\
& $(1.722)$ \\
LRGDP & $1.002^{* * *}$ \\
& $(1.538)$ \\
LINFR & $-0.004^{*}$ \\
& $(-2.024)$ \\
CONSTANT & $3.577^{* *}$ \\
& $(0.645)$ \\
\hline
\end{tabular}




\section{Fiscal Decentralization and Macroeconomic Outcomes in Nigeria}

Note: $* * *(* *) *$ denote statistical significance at the $1 \%, 5 \%$, and $10 \%$ levels, respectively. The figures in parentheses are the T-statistics.

Source: Researcher's Computation

From Table 4.5, LFGEX coefficient is 0.479 indicating a positive and significant relationship between private consumption expenditure and federal government expenditure. Therefore, a percentage point increase in federal government expenditure increases private consumption expenditure by 0.479 percent.

The coefficient of LSGEX at 0.586 indicates a positive relationship with private consumption expenditure and statistically significant at $5 \%$. This means a percentage point increase in LSGEX increases private consumption expenditure by 0.586 percent.

The coefficient of LLGEX, 0.418, signifies a positive and significant relationship with private consumption expenditure at $5 \%$. Therefore, a percentage point increase in LLGEX raises private consumption expenditure by 0.418 percent. Just as explained above in the case of state government, local government also follow the same principle.

LRGDP is 1.002 which indicates a positive and significant relationship between income level and private consumption expenditure at $1 \%$ level. Hence, a percentage points increase in income level, increases private consumption expenditure by 1.002 per cent. Theoretically, income is the largest determinant of consumption expenditure. Therefore, it is not a surprise that the impact of income on private consumption is more than proportionate. This goes on to prove the Keynesian income determination theory with respect to Nigeria.

Lastly, the coefficient of INFR, -0.004 , signifies a negative and significant relationship with private consumption expenditure at $10 \%$. Therefore, a percentage point increase in INFR decreases private consumption expenditure by 0.004 percent. This means that households are bound to reduce their level of consumption when prices increase. This is in tandem with a priori and goes on to reinforce the need to keep prices stable to enhance economic growth.

\section{Table 4.6}

Short Run Coefficients

\begin{tabular}{ll}
\hline Variables & \\
\hline D(LFGEX) & 0.095 \\
& $(1.009)$ \\
D(LSGEX) & 0.088 \\
& $(0.747)$ \\
D(LLGEX) & 0.081 \\
& $(0.819)$ \\
D(RGDP) & $1.766^{* *}$ \\
& $(2.403)$ \\
D(INFR) & $-0.001^{*}$ \\
& $(-1.087)$ \\
CointEq(-1) & $-0.700^{* * *}$ \\
& $(-3.150)$ \\
\hline
\end{tabular}

Note: ${ }^{* *}(* *) *$ denote statistical significance at the $1 \%, 5 \%$, and $10 \%$ levels, respectively. The figures in parentheses are the T-statistics.

Source: Researcher's Computation

The short run coefficients of the results indicate that none of the fiscal expenditure variables is significant at any conventional level indicating that fiscal decentralization does not affect consumption expenditure significantly in the short run. However, the control variables, real GDP and inflation rate are correctly signed and significant. The error correction term of the models with coefficient of $70 \%$ shows that the disequilibrium that occurred in the previous year will be restored back to the long run equilibrium in the subsequent year. This means that there is a high speed of adjustment to distortions to short run expected behavior of the model.

The reasons why the measures of fiscal decentralization are not significant are not limited to the fact that governance in Nigeria is fraught with corruption at all levels of government. One is therefore not surprised that short-run results of fiscal decentralization regressed on private consumption expenditure are positive but not significant. Nigeria's corruption rating has been poor over time, which is indicative of the level of misrule and poor governance at all levels of government. This directly affects the delivery 


\section{Fiscal Decentralization and Macroeconomic Outcomes in Nigeria}

of public goods and services that should impact positively on output. However, given the endemic corruption in the system, the populace is denied most of these services, hence the insignificant relationship between general government expenditure and private consumption output.

\subsubsection{Relationship between Fiscal Decentralization and Unemployment}

The study also investigated the relationship between fiscal decentralization and unemployment in Nigeria. The cointegration is established in Table 4.2. The results are presented in Tables 4.7 and 4.8 for the long run and short run coefficients respectively.

Table 4.7

Long Run Coefficients

\begin{tabular}{ll}
\hline Variables & \\
\hline LFGEX & $-0.022^{*}$ \\
LSGEX & $(-0.035)$ \\
& $-0.004^{*}$ \\
LLGEX & $(-0.006)$ \\
& 01.028 \\
LRGDP & $(2.003)$ \\
& $-2.619 *$ \\
LINFR & $(-1.949)$ \\
& $0.021 * *$ \\
CONSTANT & $(2.074)$ \\
& $28.029 * *$ \\
\hline
\end{tabular}

Note: $* * *(* *) *$ denote statistical significance at the $1 \%, 5 \%$, and $10 \%$ levels, respectively. The figures in parentheses are the T-statistics.

Source: Researcher's Computation

From Table 4.7, LFGEX and LSGEX has coefficients -0.022 and -0.004 respectively indicating inverse relationships with unemployment and significant at the $10 \%$ level. This fulfills a priori expectation and shows that that fiscal shocks emanating from both variables will results in $22 \%$ and $0.4 \%$ reduction in unemployment respectively. Consequently, if government plans on reducing the level of unemployment, an increase on investment in public goods and services will go a long way in achieving that. The theoretical background to this view is found in the Keynesian model. The model explicitly explained that when the economy is producing below the full employment level, further increases in output arising from an increase in expenditure, from any of the agents of the economy; household, firms or government will increase output. Therefore, knowing that the Nigerian economy is operating below capacity, all things been equal, an increase in federal and state governments' expenditure will result in a reduction in unemployment as the economy react to increasing demand for higher output by employing more factors of production.

The coefficient of LLGEX, 1.028, signifies a positive but not significant relationship with unemployment at any conventional level. This means that rather reduce unemployment, local government spending causes unemployment. The underlying issues for such development have been canvassed earlier in the study. These include; corruption, poor governance and structural imbalances in the federation among others see (Udoh et al 2015; Bardhan and Mookherjee, 2000). LRGDP is -2.619 which indicates a negative and significant relationship between income level and unemployment at $10 \%$ level. Hence, percentage points increase in income level, decreases unemployment level by 2.619 per cent. This is not unconnected to the fact that the level of income is a major determinant of production in the economy. Going by the simple Keynesian model, an increase in income directly leads to a boost in economic activities which engender the employment of more factors of production. One factor of production that can be varied with changing levels of output in the short-run is labour. Consequently, it follows a priori to see a positive and significant impact of income (real GDP) on unemployment.

Lastly, the coefficient of INFR, 0.021, signifies a positive and significant relationship with unemployment at $5 \%$. Therefore, a percentage point increase in INFR increases unemployment by 0.021 percent. A rise in the general price level (inflation) is inversely related to the level of production. Rising level of prices naturally dissuade firms from producing more as consumers cut their level of consumption in reaction to existing realities. The natural outcome is reduction in employment of more factors of production by the firms, hence breeding unemployment in reaction to the general price level. 
Fiscal Decentralization and Macroeconomic Outcomes in Nigeria

\section{Table 4.8}

Short Run Coefficients

\begin{tabular}{ll}
\hline Variables & $-0.018^{*}$ \\
\hline D(LFGEX) & $(-0.035)$ \\
& $-0.003^{*}$ \\
D(LSGEX) & $(-0.006)$ \\
& -0.865 \\
D(LLGEX) & $(1.885)$ \\
& $-2.205^{*}$ \\
D(RGDP) & $(-1.879)$ \\
& 0.003 \\
D(INFR) & $(.419)$ \\
& $-842 * * *$ \\
CointEq(-1) & $(-4.846)$ \\
\hline
\end{tabular}

Note: ${ }^{* *}(* *) *$ denote statistical significance at the $1 \%, 5 \%$, and $10 \%$ levels, respectively. The figures in parentheses are the T-statistics.

Source: Researcher's Computation

From Table 4.8, there exists evidence of long run relationship. This can be seen through the error correction term of the model. Here the coefficient suggests that about $84 \%$ of the disequilibrium that occurred in the previous year will be restored back to the long run equilibrium in the subsequent year.

With regards to the coefficients, most of the variables in the short run have the same direction of relationship as in the long run presented in Table 4.7. This is except for inflation rate which is found not statistically significant at any conventional level. The possible explanation could be that some level of inflation is needed to spur production theoretically. Therefore, mild levels of inflation may not significantly impact production and by extension unemployment unless when it becomes high and sustained over time.

\section{CONCLUSION}

From the findings of this study, the following conclusions are derived:

(i) The ARDL result shows the existence of long-run equilibrium among the variables used in the study.

(ii) In model 1, measures of fiscal decentralization are seen to have a positive and significant effect on economic growth in the long and short run except for local government expenditure which is positive but not significant at any conventional level.

(iii) Model 2 shows that private consumption expenditure is positively and significantly affected by national income (RGDP) both in the short and long-run. This is in tandem with the Absolute income hypothesis which identifies income as a major determinant of consumption.

(iv) Model 2 also indicate that measures of fiscal decentralization affect private consumption expenditure positively in the long-run except for local government expenditure which is not significant at any conventional level. In the shortrun, none of the fiscal decentralization variables significantly affected private consumption expenditure.

(v) In model 3, results show inverse relationship between fiscal decentralization variables of FGEX and SGEX as well as real GDP and unemployment (UMPR). However, none of the variables were statistically significant in affecting unemployment both in the short and long-run.

(vi) Contrary to a priori expectation, local government expenditure (LGEX) do have a positive linear none significant effect on unemployment both in the long and short-run. This means that fiscal shocks from local government expenditure though insignificant, cause an increase in the level of unemployment. The possible causes of this abnormal behavior are highlighted in the result discussion section.

(vii) Similarly, bi-directional causality is found between private consumption expenditure and federal government expenditure. This means that an increase in federal government expenditure increase private consumption expenditure, vise-versa. However, there is no evidence of causality or feedback causation running from unemployment to private consumption expenditure and unemployment to local government expenditure, at least for the period under study. 


\section{Fiscal Decentralization and Macroeconomic Outcomes in Nigeria}

\subsection{Policy recommendations}

1. A review of the revenue sharing formula and the existing fiscal structure should be initiated by the National Assembly to reflect the rising expenditure needs of the subnational governments. The current structure is creating a leviathan out of the federal government which tends to impede growth of the economy.

2. The fiscal relations between the States and Local Councils must reviewed to repeal the joint account arrangement and restore local governments autonomy to ensure effective service delivery at that level of government.

3. Enabling laws on budget preparation and implementation such as the "Public Procurement Act" must be followed religiously to enhance expenditure at all levels of governance.

4. A strong relationship exists between economic growth and private consumption expenditure. Fiscal policy measures aimed at expanding disposable income such as transfers, tax reduction and subsidies will enhance household consumption expenditure and macroeconomic outcomes.

5. Targeted interventions in agriculture and micro, small and medium enterprises will boost growth and reduce the level of unemployment through deliberate coordination and implementation.

6. The short-run dynamics has shown that fiscal decentralization measure hardly has impact on macroeconomic aggregates. Consequently, government expenditure in the short-run must be precise and deliberate to avoid the short-run dynamics spilling over to the long-run which could generally limit the growth potentials of the economy.

\section{REFERENCES}

1) Adefeso, H. A. (2014) Local Decentralization and Economic Growth in Nigeria. Acta Universitatis Danubuis (Economica 10(3), 102-115

2) Amire C. M. and M. O. Okufuwa (2020), Fiscal Federalism and Nigeria Economic Development: Prospect and Challenges, American Journal of Economics, 10(3), 172-186.

3) Bardhan, P. and Mookherjee, D. (2000) Capture and Governance at Local and National Levels. American Economic Review. 90 (2) 135-139.

4) Canavire-Bacarreza, G., J. Martinez-Vazquez and B. Yedgenov (2019), Identifying and Disentangling the Impact of Fiscal Decentralization on Economic Growth. Inter-American Development Bank. IDB Working Paper Series; 1037.

5) Davoodi, H., Zou, H., (1998) "Fiscal Decentralization and Economic Growth - A Cross-Country Study" Journal of Urban Economics 43: 244-57

6) Eshenake S.J. and D. O. Oyovwi (2013). Fiscal Federalism and Economic Welfare in Nigeria: an Econometric Analysis. European Journal of Sustainable Development. 2(3), 65-76

7) Ewetan, O. O., O. A. Matthew., A. A. Babajide., R. Osabohien \& E. Urhie (2020) Fiscal Federalism and Economic Development in Nigeria: An auto-regressive distributed lag approach, Cogent Social Sciences, 6:1.

8) Feld, L. P., G. Kirchgassner, and C. A. Schaltegger (2004), Fiscal Federalism and Economic Performance: Evidence from Swiss Cantons. Mimeo, Philips University, Marburg.

9) Hanif, I., S. Wallace, and P. Gago-de-Santos (2020), Economic Growth by Means of Fiscal Decentralization: An Empirical Study for Federal Developing Countries. Sage 1-12.

10) Jin, Y. and M. Rider (2020) Does Fiscal Decentralization Promote Economic Growth? An Empirical Approach to the study of China and India. Journal of Public Budgeting, Accounting \& Financial Management.

11) Martinez-Vazquez, J and R. McNab (2001) Fiscal Decentralization and Economic Growth.Working Papers No. 1-1. Calhoun International Studies Program.

12) Martinez-Vasquez, J and R. McNab (2003), Fiscal Decentralization and Economic Growth. World Development 31 (9), 1597-1616.

13) Guldner, M., (1995), "Health Care in Transition in Vietnam: Equity and Sustainability". Health Policy and Planning, Vol.10, 49-62.

14) Harris, R. and Sollis, R. (2003), Applied Time Series modeling and Forecasting. Chichester: Wiley and Sons.

15) Hayek, F.A. (1945). The Use of Knowledge in Society. American Economic Review. 45, 519-530.

16) Jin, Y. and M. Rider (2020) Does Fiscal Decentralization Promote Economic Growth? An Empirical Approach to the study of China and India. Journal of Public Budgeting, Accounting \& Financial Management.

17) Johansen, S. and Juselius, K. (1990), "Maximum Likelihood Estimation and Inferences on Cointegration-with Applications to the Demand for Money," Oxford Bulletin of Economics and Statistics, (52):169-210.

18) Layard, R. and A. Walters (1978). Microeconomic Theory. McGraw-Hill, New York.

19) Musgrave, R. (1959). The Theory of Public Finance. NY: McGraw-Hill 


\section{Fiscal Decentralization and Macroeconomic Outcomes in Nigeria}

20) Musgrave, R and M. Musgrave (1984), Public Finance in Theory and Practice, Harper and Row, New York

21) Oates, Wallace E. (1972), Fiscal Federalism. New York: Harcourt Brace Jovanovich.

22) Oates, Wallace E, (1993) Decentralization and Economic Development. National tax Journal. 46. $237-757$.

23) Pesaran, M.H., Shin, Y., and Smith, R.J. (2001), "Bound Testing Approaches to the Analysis of Level Relationship," Journal of Applied Economics, (16):289-326.

24) Ramphal, S. S. (1979), Keynote Address. In: Readings on Federalism. Lagos; Nigerian Institute of International Affairs.

25) Taiwo, I.O.(1999), Fiscal Federalism: A Theoretical Framework. A Paper Presented at the Annual Conference of the Nigerian Economic Society, 3-23.

26) Tanzi, V. (2001), Pitfalls on the Road to Fiscal Decentralization. Carnegie Endowment Working Papers No 19.

27) Tiebout, C. M. (1956). A Pure Theory of Local Expenditure, Journal of Political Economy, 64, 416-424

28) Udoh, E., U. Afangideh and E. A. Udeaja (2015) Fiscal Decentralization, Economic Growth and Human Capital Development in Nigeria: Autoregresive Distributed Lag Approach. CBN Journal of Applied Statistics 6(1a), 69-93. 